\title{
THE CYCLE OF PHOSPHORUS IN THE WATERS OF THE ENGLISH CHANNEL
}

\author{
By F. A. J. Armstrong and H. W. Harvey, F.R.S. \\ From the Plymouth Laboratory
}

(Text-figs. I-IO)

A study of the distribution of phosphorus compounds-in solution in the water, in planktonic, in free-swimming and in bottom-living organisms, in detritus and in deposits on the sea floor-forms a natural sequence to two groups of observations which have been made in recent years. The one group has shown that water masses have been present in the mouth of the English Channel containing very different concentrations of phosphate in winter, when the phosphate concentration reaches a maximum-concentrations ranging from Io $\mathrm{mg}$. phosphate-P per cubic metre in some water masses to over $20 \mathrm{mg}$. in others. The second group of observations has shown a great difference in the population density of macroplankton between one water mass and another, and, also, more macroplankton and a better survival of young fish in the waters off Plymouth during years when the winter maximum of phosphate in the water was greatest.

The aim of this present study is twofold: towards finding a constituent of sea water which is unaffected by seasonal changes and whose concentration differentiates one water mass from another, and towards a further insight into those factors which affect the fertility of an area of the sea and cause fluctuations in population during the course of years.

Most of the data have been collected at a distance of 20 miles off shore from Plymouth in a depth of $70 \mathrm{~m}$. The water occupying this area does not stay there; as shown by changes in salinity, it is replaced by other water masses at frequent and irregular intervals. Since it is impracticable to follow one particular water mass in its wanderings and intermingling throughout a year, seasonal changes in a particular water mass cannot be determined directly. From observations at one position small seasonal changes may not be apparent and could be demonstrated only by a series of observations taken at one position throughout many years, sufficient for fluctuations due to changing water masses to iron themselves out.

On the other hand, the considerable seasonal changes which occur in phosphate, nitrate, phyto- and zooplankton are quite apparent. They outweigh fluctuations arising from a succession of water masses passing through the area.

The earlier attempts to estimate organic phosphorus compounds in solution in the sea were vitiated by the use of a method of analysis which included in 
the estimate any arsenate present (Kreps \& Osadchik, I933; Kalle, I933; Seiwell \& Seiwell, 1934).

This analytical difficulty was overcome by Kalle (1935, 1937), who then surveyed a considerable area of the southern North Sea in the winter of 1935. $\mathrm{He}$ envisaged the probability that the total phosphorus in dissolved compounds was a distinction between water masses-'Hilfsmittel zur Unterscheidung von Wasserkörpern'.

His investigation showed very different concentrations of total phosphorus and of phosphate in January in different areas of the North Sea. It also showed that the more turbid waters contained large quantities of this element in suspension.

During the same year, another analytical method was devised by Redfield, Smith \& Ketchum (1937), which also eliminated interference by arsenic. They estimated phosphate in solution, total phosphorus and phosphorus in particulate matter retained on a filter, at a position in the Gulf of Maine on five occasions during a year, to a depth of some $250 \mathrm{~m}$.

The position lay in a water mass which is considered subject to but little interchange with the surrounding water. During the course of the year, there was no marked difference in the total phosphorus in the water column between summer and winter.

May 1935 Aug. Nov. Feb. 1936 May

Their research showed that the integral mean concentration of total phosphorus in a water column could be used to distinguish one water mass from another at any time of year.

A series of total phosphorus estimations have also been made in the nutrientpoor waters of the Adriatic, at intervals throughout a year, using Kalle's method (Nümann, I94I). The data provide no indication of any seasonal change in the total phosphorus content, but the quantity is very small, averaging $5 \mathrm{mg}$. $\mathrm{P} / \mathrm{m}{ }^{3}$, compared with over $30 \mathrm{mg}$. in the Gulf of Maine, $\mathrm{I} 2 \mathrm{mg}$. off Plymouth during recent years and, by inference, over $20 \mathrm{mg}$. during the relatively rich period some 25 years ago.

The main difficulty in further investigation lay in the uncertainties inherent in the technique of estimation. Even the estimation of dissolved phosphate at great dilutions embraces reactions which are imperfectly understood; this is indicated by several papers appearing every year on modifications of the molybdenum blue method.

An examination has been made of the reactions involved in phosphate estimation and, also, a more simple and rapid variant of the method used by Redfield et al. to estimate total phosphorus in water samples has been developed (Harvey, I948; Armstrong, I949). The sample is acidified to $0.28 \mathrm{~N}$ and heated for $5 \mathrm{hr}$. at $130^{\circ} \mathrm{C}$; this treatment in the presence of chloride appears to hydrolyse all or almost all the organic phosphorus compounds; any 
arsenate present is reduced with sulphite. Large quantities of arsenate may be added to the sea-water sample without showing any increase in the estimate of total phosphorus.

On the other hand when a sample of sea water is analysed for inorganic phosphate, the estimate by molybdenum blue includes the equivalent of any arsenate which may be present in the water. This amount is unknown.

Analyses of English Channel waters have shown the presence of some $19 \mathrm{mg}$. As per $\mathrm{m}^{3}$ (Orton, I923), which compares with 7-24 mg. in more recent analyses of Atlantic waters (Rakestraw \& Lutz, I933) and $15-38 \mathrm{mg}$. in Pacific waters (Gorgy, Rakestraw \& Fox, 1948). The latter authors found that from $8-16 \%$ of the whole existed as arsenate.

Based on the value of $19 \mathrm{mg}$. As $/ \mathrm{m} \cdot{ }^{3}$ in English Channel waters, this suggests that $\mathrm{I} \cdot 5-3 \mathrm{mg}$. may be present as arsenate. These quantities would appear in the estimated concentration of phosphate as $0 \cdot 6-\mathrm{I} \cdot 2 \mathrm{mg}$. $\mathrm{P}$ of phosphate-P actually present.

Some experiments made during this investigation are of interest. When sea water is autoclaved with acid, as in the estimation of total phosphorus but without added sulphite, any added arsenite is oxidized to arsenate. This treatment would also be expected to disrupt any organic arsenic compounds, which are likely to be present in sea water because many marine organisms concentrate arsenic in their tissues.

Thus the difference in molybdenum blue developed in waters which have been acidified and autoclaved with and without added sulphite, gives an indirect measure of the arsenic present. Estimations in waters collected off Plymouth in 1947 gave values amounting to $3.1,2.6$ and $2.4 \mathrm{mg}$. As $/ \mathrm{m}^{3}$, in a water collected in 1948 only I mg. As, and in a composite sample collected in $1949,2.1 \mathrm{mg}$. As, there being less in the same water after filtration.

These were unexpectedly low values, in view of the direct estimations of total arsenic made in England and America by the methods of Marsh and Gutzeit respectively.

Some further observations made during this investigation suggest that little or no arsenite may be present as such in the sea. When a solution of sodium arsenite was added to samples of sea water at $\mathrm{pH} 8-8 \cdot 2$, increasing the concentration by $40 \mathrm{mg}$ As $/ \mathrm{m}^{3}{ }^{3}$, it was oxidized to arsenate. This happened rapidly in some waters, slowly in others.

We do not know what proportion of the estimated values of phosphate-P are due to arsenate; there is conflicting evidence of how much to expect.

Since June 1947 samples taken from a series of depths, at the position 20 miles off-shore, have been analysed for phosphate and for total phosphorus.

\section{Distribution of Phosphorus in the English Channel}

In winter, 20 miles off-shore from Plymouth and elsewhere in the English Channel, both phosphate and total phosphorus remained almost constant throughout the water column. Filtering the water had negligible effect-the quantity of phosphorus in particulate form is then very small indeed. Replicate samples taken from the same depth show only small differences between each other. The distribution shown in Fig. I is typical of winter conditions in this area; phosphate-P accounts for some $90 \%$ of the total.

Fig. 2 is derived from the data by Redfield et al. in the Gulf of Maine. Here there appears to be a different water mass below $170 \mathrm{~m}$., in which practically all 


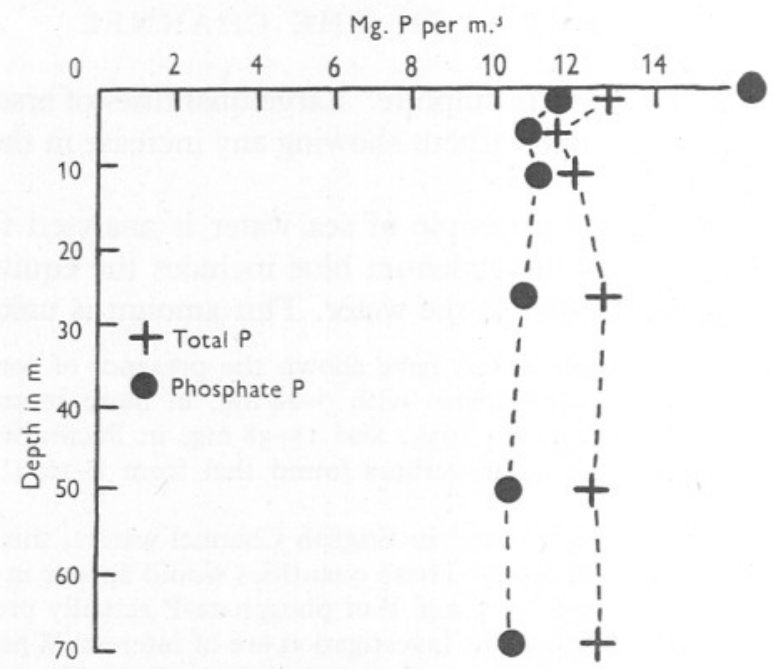

Fig. I. Distribution of total and of phosphate-P in the water, 20 miles off shore, 5. i. 49 . Depth $70 \mathrm{~m}$.

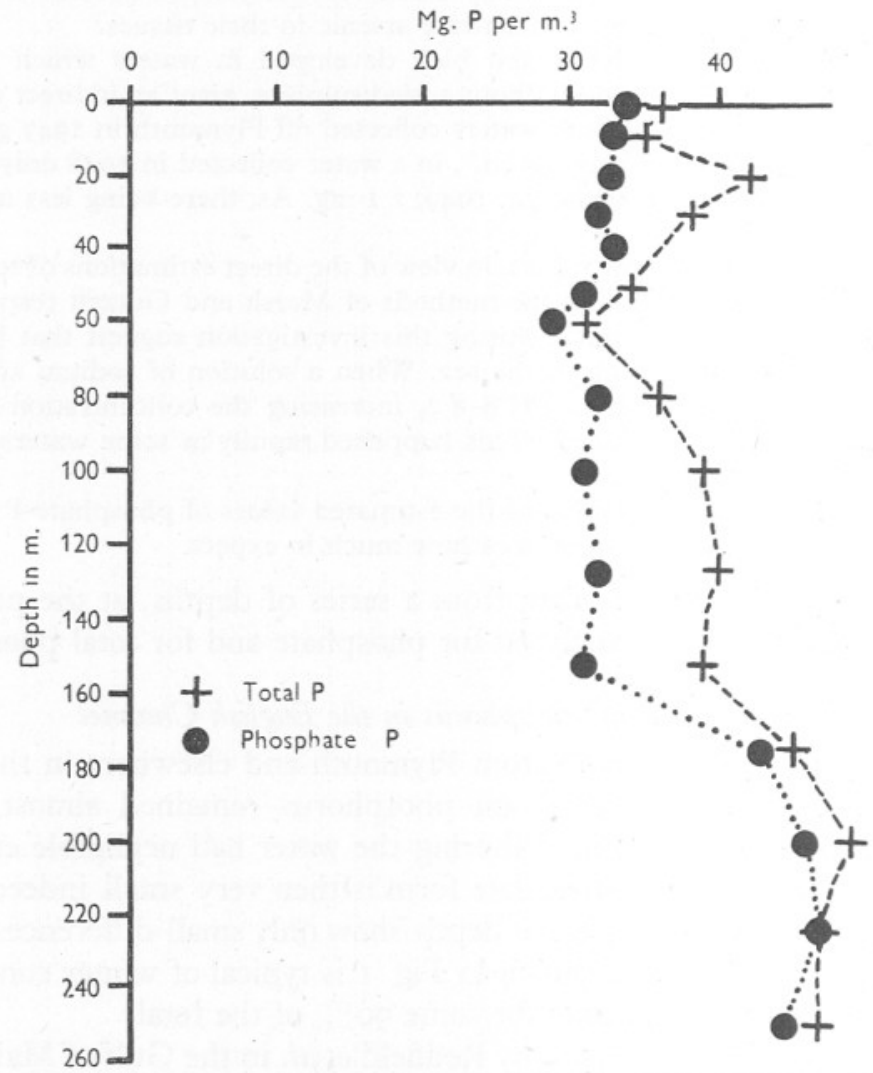

Fig. 2. Distribution of total and of phosphate-P in the Gulf of Maine, 26. ii. 36. From data by Redfield, Smith \& Ketchum (1937). 
the organic phosphorus has reverted to phosphate, whereas above $170 \mathrm{~m}$. phosphate-P accounts for some $90 \%$ of the total.

In the waters so far investigated at the time of the winter phosphate maximum, the phosphate in the water columns amounts to $85-90 \%$ of the total phosphorus.

During the winter months, in particular, there is an odd phenomenon which we have frequently observed. If the water sample is taken from the surface, it often contains rather more total phosphorus and more phosphate than occurs in the water below. The cause is not obvious; possibly dust from the atmosphere may become trapped by surface tension at the air surface, or particles in suspension may attach to themselves minute bubbles of air during rough weather when waves are breaking, and these, rising to the surface, become entrapped. Both Söderstrom (I924) and Wilson (I932) have observed that when larvae of Polygordius and of Owenia come into contact with the surface they are held there and even torn apart by the surface forces. Suspended matter removed by filtration from water collected at the surface of the sea was rich in phosphorus. On two occasions it accounted for $5 \cdot 5$ and $2 \cdot 2 \mathrm{mg} . \mathrm{P} / \mathrm{m}^{3}$.

As the year advances, some redistribution takes place. Phosphate is used by the plants in the upper layers. Zooplankton, rising into these layers at night, graze on the plants and retiring by day excrete phosphate and soluble organic phosphorus compounds into the water below. Thus, until June, organic phosphorus compounds increase at the expense of phosphate. Most of this increase is in the form of dissolved organic $\mathrm{P}$, since the quantity of phosphorus in the plankton never increases beyond a small fraction of that in solution. Also throughout the summer, there is less total phosphorus in the upper layers, due to vertical transport by plant-eating zooplankton, than in the water below. In several of our observations in summer there was a slight but significant accretion of phosphorus between 20 and $40 \mathrm{~m}$. depth.

From February to June in I948 and I949 the dissolved organic plus particulate phosphorus increased from Io or I2 \% to some $65 \%$ of the total in the $70 \mathrm{~m}$. water column off Plymouth. A typical distribution is shown in Fig. 3, while Fig. 4 shows the distribution in the deeper water of the Gulf of Maine in August.

In order to determine the very small quantity of phosphorus present in particulate matter in suspension, samples were collected at regular intervals of depth and mixed to give a composite sample, representative of the whole water column. Part was filtered through No. 42 Whatman paper. From this and the unfiltered remainder, replicate subsamples were taken for analysis. The difference between the mean values for the filtered and unfiltered samples gave a measure of the phosphorus in particulate matter. Table I shows the results of these analyses; it also includes the calculated quantity of phosphorus present in zooplankton and plants. The data from which these values were derived are given in a separate communication (Harvey, I950, pp. 97-I37). 


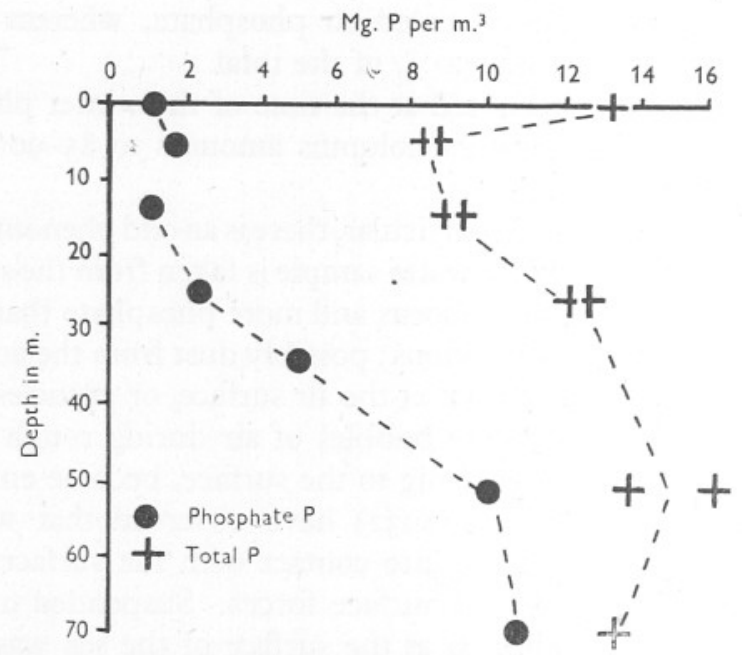

Fig. 3. Distribution of total and of phosphate-P in the water 20 miles off shore, 3I. viii. 48. Depth $70 \mathrm{~m}$.

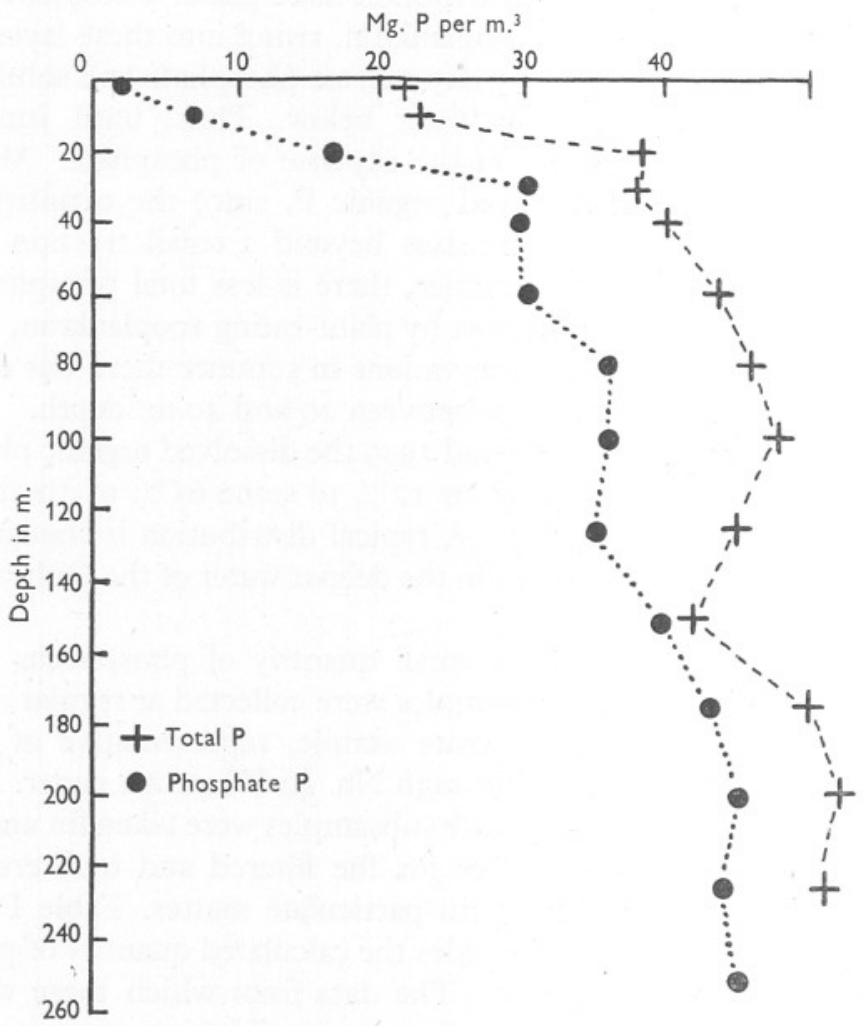

Fig. 4. Distribution of total and of phosphate-P in the Gulf of Maine, 2I. viii. 35. From data by Redfield, Smith \& Ketchum (1937). 
By subtracting the quantity in living plankton from the total, a rough estimate is obtained of the quantity in detritus. This is thought to be mostly organic detritus, fragments of once-eaten diatoms and zooplankton, which can be seen present in the water after the spring flowering of diatoms in early April.

Table I. Analyses of Total P, Mg. Per $M .^{3}$, in COMPOSITE SAMPLES FROM 20 Miles OFF-SHORE

\begin{tabular}{|c|c|c|c|c|c|c|c|c|}
\hline \multirow{7}{*}{ Unfiltered } & I. iii. 49 & I3. iv. 49 & 9. v. 49 & 9. vi. 49 & 6. vii. 49 & 8. viii. 49 & 8. ix. 49 & 8. xi. 49 \\
\hline & I5 & 16.4 & 14.9 & II 6 & II $\cdot 7$ & II $\cdot 0$ & 12.8 & $\mathrm{I} 2 \cdot \mathrm{I}$ \\
\hline & I3.7 & 16.9 & I 4.7 & I2. I & II.9 & 10.2 & I $2 \cdot I$ & I 2.5 \\
\hline & 13.3 & 15.6 & $I 4 \cdot I$ & II.9 & 12.0 & $9 \cdot 6$ & 12.9 & 12.6 \\
\hline & & 15.5 & I2.6 & II $\cdot 8$ & II 6 & 10.3 & I $2 \cdot 4$ & I3.I \\
\hline & & $16 \cdot 3$ & 14.6 & $12 \cdot 0$ & I 2.4 & 9.0 & I $2 \cdot 3$ & 15.5 \\
\hline & & $16 \cdot 2$ & $\begin{array}{l}\text { I } 4 \cdot 6 \\
\text { I } 4 \cdot 6\end{array}$ & II 9 & 12.5 & 10.4 & & I3.8 \\
\hline \multirow{5}{*}{$\begin{array}{l}\text { Av. } \\
\text { Filtered }\end{array}$} & $\mathrm{I} 4 . \mathrm{O}$ & $I 6 \cdot 15$ & $\mathrm{I} 4 \cdot 3$ & II $\cdot 9$ & $12 \cdot 0$ & IO. I & 12.5 & I3.3 \\
\hline & 13.3 & $\mathrm{I} 4.8$ & II 3 & $9 \cdot 7$ & 10.5 & $9 \cdot I$ & II 9 & I3. I \\
\hline & 13.6 & I 4.7 & II 4 & 10.0 & 10.4 & $8 \cdot 5$ & $12 \cdot 2$ & $13 \cdot 7$ \\
\hline & 13.5 & 14.6 & II $\cdot 7$ & & I0.7 & $8 \cdot 9$ & $12 \cdot 0$ & \\
\hline & & I 4.9 & II $\cdot 2$ & & 10.4 & $8 \cdot 9$ & & \\
\hline Av. & I3.5 & I 4.75 & II 4 & $9 \cdot 9$ & 10.5 & $8 \cdot 9$ & $12 \cdot 03$ & I3.4 \\
\hline $\begin{array}{l}\mathrm{P} \text { in particulate } \\
\text { matter (by } \\
\text { difference) }\end{array}$ & 0.5 & I. 4 & $2 \cdot 9$ & 2 & $\mathrm{I} \cdot 5$ & $I \cdot 2$ & 0.45 & - \\
\hline $\begin{array}{l}\mathrm{P} \text { in phyto- } \\
\text { plankton }\end{array}$ & 0.13 & 0.42 & 0.78 & 0.5 & $<0.5$ & $<0.5$ & $<0.4$ & - \\
\hline $\mathrm{P}$ in zooplankton & 0.2 & 0.8 & $I \cdot O$ & 0.5 & 0.5 & 0.5 & 0.4 & 一 \\
\hline $\begin{array}{l}\text { In detritus } \\
\text { (by difference) }\end{array}$ & 0.2 & 0.2 & $I \cdot I$ & $I \cdot 0$ & 0.5 & 0.2 & - & 一 \\
\hline
\end{tabular}

The nature of the particles of inorganic phosphate likely to occur in turbid waters is of interest. Dietz, Emery \& Shepard (I942) have described sedimentary deposits of calcium phosphate, containing fluoride, which were laid down off the Pacific coast of America. They conclude that sea water is fully saturated with respect to calcium phosphate. Cooper (I948 $a, b)$ considers that particles in suspension are likely to consist of ferric phosphate, which is one of the most insoluble phosphates, and that these particles, once formed, may hydrolyse somewhat slowly in sea water. As a statistical average, waters richer in iron were also richer in phosphate.

With regard to this possibility, the following experiment is of interest.

Ferric phosphate was prepared and very thoroughly washed. The addition of this to a culture of phosphate-starved diatoms was followed by a prolific growth; this also happened when it was enclosed in a cellophane sac and suspended in the culture.

When added to sea water in a stoppered vessel, the $\mathrm{pH}$ quickly fell to $c$. 7. The water was poured off and replaced, the $\mathrm{pH}$ of this fresh sea water fell in the same way. The fall in $\mathrm{pH}$ of successive replacements of sea water became progressively slower.

The conclusion arrived at was that hydrolysis takes place at $\mathrm{pH} 8$, becoming infinitely slow at c. $\mathrm{pH} 7$, and that the rate of hydrolysis is much greater the finer the particles. 
In addition to the estimates made in waters 20 miles off-shore, estimations have been made from time to time at positions nearer Plymouth. Sometimes there was rather less phosphorus in the water and at other times more. The distribution in January 1949 is shown in Fig. 5, when a 'richer' water lay nearer the shore. The high concentrations occurring in water collected from the surface on this occasion are noteworthy.

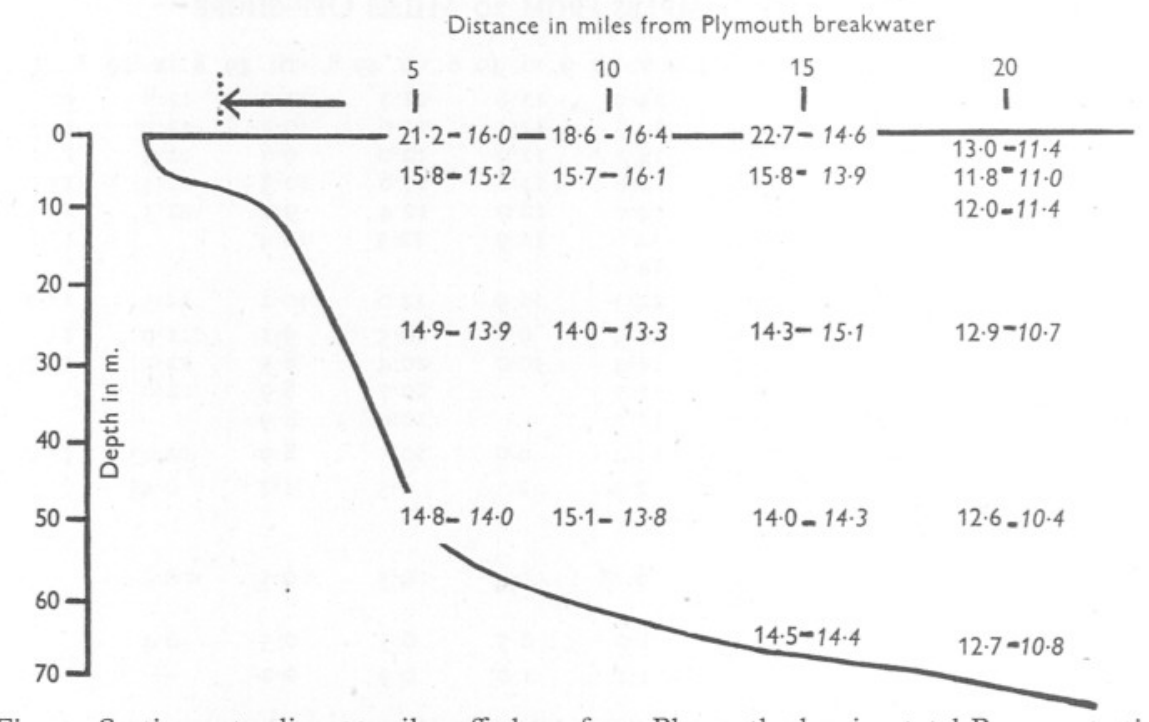

Fig. 5. Section extending 20 miles off-shore from Plymouth showing total-P concentration (upright type) and phosphate-P (italics) in $\mathrm{mg} . / \mathrm{m}^{3}$. 5 and $\mathrm{I} 4$. i. 49.

The integral mean concentrations of total and phosphate-P in the whole water column at the position 20 miles off-shore are shown in Fig. 6.

The total has fluctuated in an irregular manner between $9 \frac{1}{2}$ and $16 \mathrm{mg}$. $\mathrm{P} / \mathrm{m} .^{3}$, while the salinity of the waters sampled fluctuated between $35^{\circ} 0$ and $35.4 \%$.

No relation is apparent between the fluctuations in total phosphorus and in salinity.

It is thought that the fluctuations in total phosphorus are almost entirel due to richer or poorer water moving into the area. Yet it is, of cours, possible that incursions of water have by chance masked a seasonal change phosphorus content. Only a series of observations extending over many yes would rule out this possibility.

Further evidence bearing upon a possible seasonal variation was theref sought in two directions: (I) whether organic detritus is deposited on the floor after the spring maximum of planktonic life and slowly regener phosphate; (2) whether the quantity of phosphorus locked up in living organ which die during the autumn and winter months is at all considerable. Ne 
inquiry provided evidence indicating a material seasonal change in the total phosphorus in the water.

It was considered that if any deposition of organic matter takes place, it would lie on the sea floor as a sludge or slurry. Therefore an apparatus was constructed which sucks in water from close to the bottom very rapidly. A strong spring is released when the foot of the apparatus touches bottom, retracting a piston which sucks in water with a rush. Fitting a longer foot allowed samples also to be taken from $35 \mathrm{~cm}$. above the bottom.

Samples taken close to the bottom contained a little organic detritus and a little silt in addition to sand grains. Their phosphorus content was little greater than that in samples taken from water above (Table II). No evidence was found of any material deposition of detritus rich in phosphorus.

\begin{tabular}{|c|c|c|c|}
\hline $\begin{array}{l}\text { I2. v. } 48 \\
20 \text { miles off-shore }\end{array}$ & $\mathrm{mg} . \mathrm{P} / \mathrm{m}^{3}$ & $\begin{array}{l}\text { 23. vii. } 47 \\
\text { I3 miles off-shore }\end{array}$ & $\mathrm{mg} . \mathrm{P} / \mathrm{m}$. \\
\hline $5-6 \mathrm{~cm}$. above bottom & $\mathrm{I} 6 \cdot 5, \mathrm{I} 4.5$ & $5-6 \mathrm{~cm}$. above bottom & $18 \cdot 0,24 \cdot 0$ \\
\hline $\begin{array}{l}35 \mathrm{~cm} \text {. above bottom } \\
5 \mathrm{~m} \text {. above bottom }\end{array}$ & $\begin{array}{ll}12.4 \\
-156\end{array}$ & $35 \mathrm{~cm}$. above bottom & $14 \cdot 7$ \\
\hline $\begin{array}{l}5 \mathrm{~m} \text {. above bottom } \\
25 \mathrm{~m} \text {. above bottom }\end{array}$ & $9 \cdot 6$ & $\begin{array}{l}3 \mathrm{~m} \text {. above bottom } \\
8 \mathrm{~m} \text {. above bottom }\end{array}$ & $\begin{array}{l}14 \cdot 2 \\
\mathrm{I} 3 \cdot \mathrm{I}\end{array}$ \\
\hline $50 \mathrm{~m}$. above bottom & $10 \cdot 3$ & & \\
\hline $\begin{array}{l}\text { 29. ix. } 47 \\
\text { I3 miles off-shore }\end{array}$ & $\mathrm{mg} . \mathrm{P} / \mathrm{m}^{3}$ & $\begin{array}{c}\text { 29. ix. } 47 \\
5 \text { miles off-shore }\end{array}$ & $\mathrm{mg} . \mathrm{P} / \mathrm{m}^{3}{ }^{3}$ \\
\hline $\begin{array}{l}5-6 \mathrm{~cm} \text {. above bottom } \\
35 \mathrm{~cm} \text {. above bottom }\end{array}$ & $\begin{array}{l}\mathrm{I} 4 \cdot 2, \mathrm{II} \cdot 4 \\
\mathrm{II} \cdot 4\end{array}$ & $\begin{array}{l}5-6 \mathrm{~cm} \text {. above bottom } \\
\text { I } 5 \mathrm{~m} \text {. above bottom }\end{array}$ & $\mathrm{II} \cdot 4, \mathrm{I} 5 \cdot 7$ \\
\hline $\begin{array}{c}35 \mathrm{~cm} \text {. above bottom } \\
3 \mathrm{~m} \text {. above bottom }\end{array}$ & $\begin{array}{l}\text { II. } 4 \\
\text { IO.2 }\end{array}$ & $\begin{array}{l}\text { I5 } \mathrm{m} \text {. above bottom } \\
25 \mathrm{~m} \text {. above bottom }\end{array}$ & $\begin{array}{ll}14.0 \\
-12.6\end{array}$ \\
\hline $16 \mathrm{~m}$. & $10 \cdot 7$ & & \\
\hline
\end{tabular}

Computations of the phosphorus in fish and bottom fauna, as incorporated in Fig. Io, amounted to a fifth of the whole below a square metre. Since these animals probably grow most rapidly in spring and early summer a quite small seasonal variation of phosphorus, dissolved and suspended in the water, is indicated.

The data for the mean integral concentration of total and of phosphate-P in the water column, presented in Figs. 6 and 7, permits the ratio of phosphate to organic phosphorus in the water column to be calculated on each occasion when a series of samples had been collected and analysed. This ratio is shown in Fig. 8. Except for a single occasion, the seasonal change in the ratio has followed a remarkably constant course.

On this exceptional occasion, 9 June 1949, the percentage of phosphate was greater than a month earlier or a month later. The changes in salinity and temperature which had occurred provided no explanation of this. It is thought that there had moved into the area a body of water in which plant life had been less abundant during the previous 3 months.

It is seen from Figs. 7 and 8 that, from the end of January until June, the 
rate at which organic phosphorus compounds are being excreted is greater than the rate at which they are changing into phosphate. The most rapid increase in dissolved organic phosphorus took place in March and April, when production of plants was at its height; it ceased some time in June when the temperature was rising rapidly and organic detritus in suspension had reached

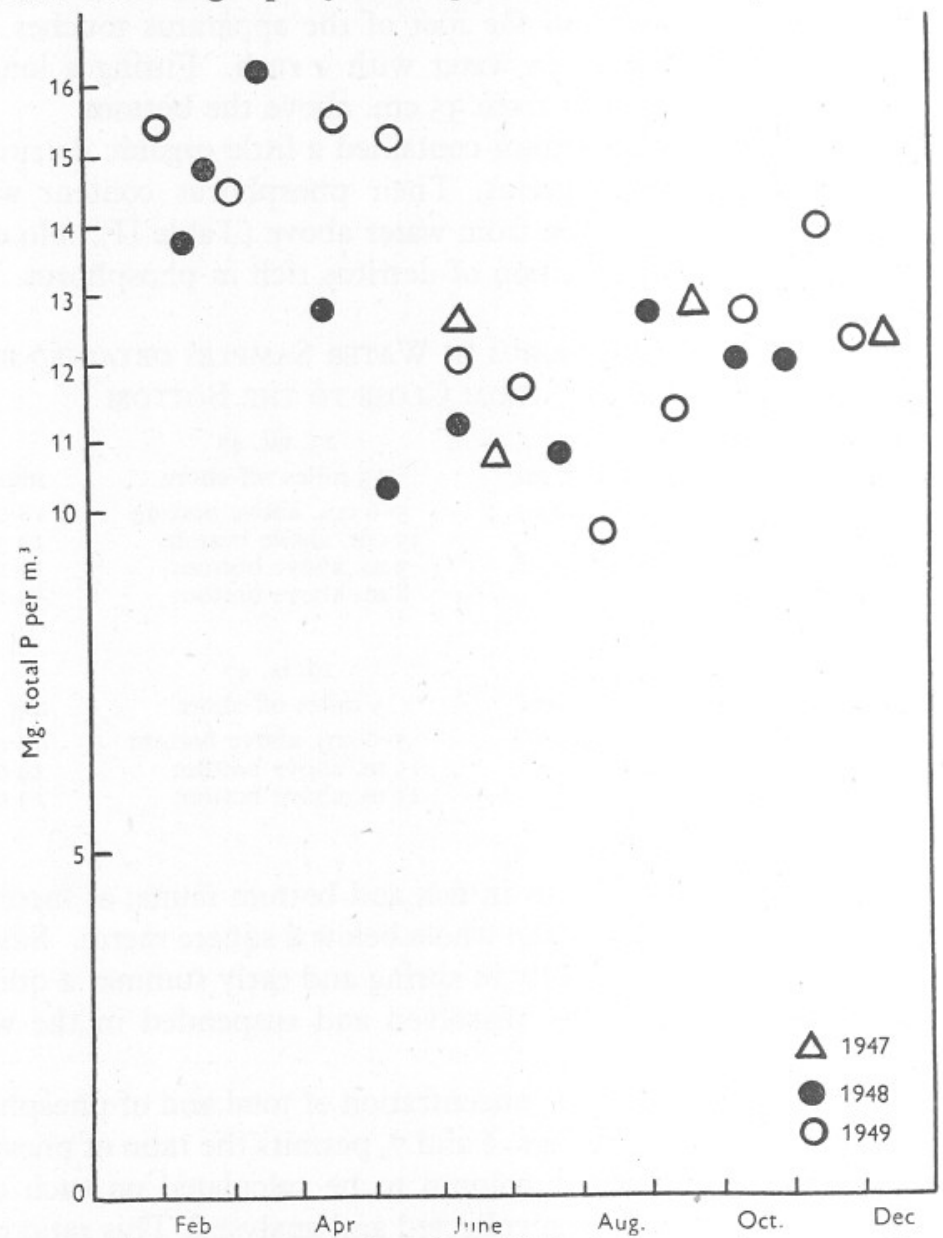

Fig. 6. The integral mean concentration of total-P in the water column 20 miles off shore.

a maximum. The increase ceased and phosphate started to increase long before the temperature of the sea reached its maximum in August.

There is no evidence whether breakdown of organic phosphorus compounds is mostiy due to slow chemical decomposition or to bacterial action. If the latter, a seasonal variation in numbers of bacteria in the water would be indicated. This is not unlikely, because they grow rapidly on any surfaces such as those presented by particles of detritus in suspension. 


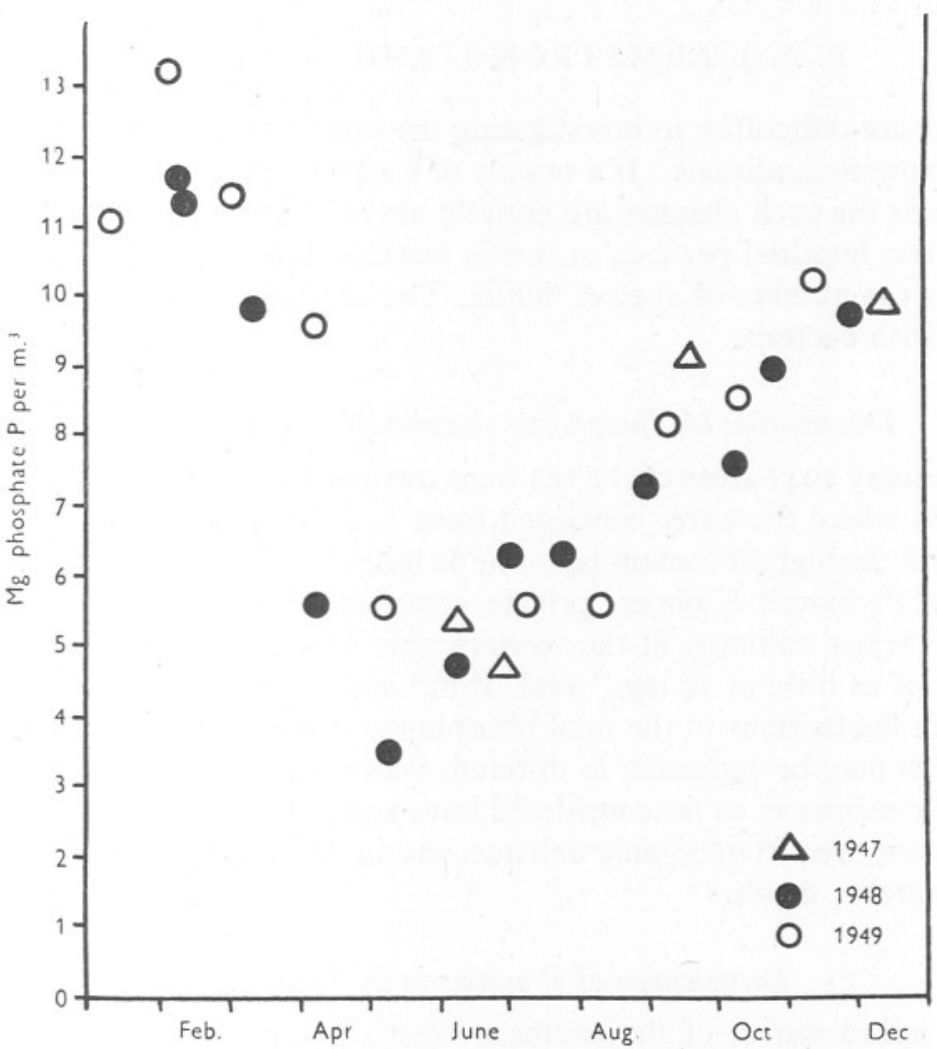

Fig. 7. The integral mean concentration of phosphate-P in the water column 20 miles off-shore.

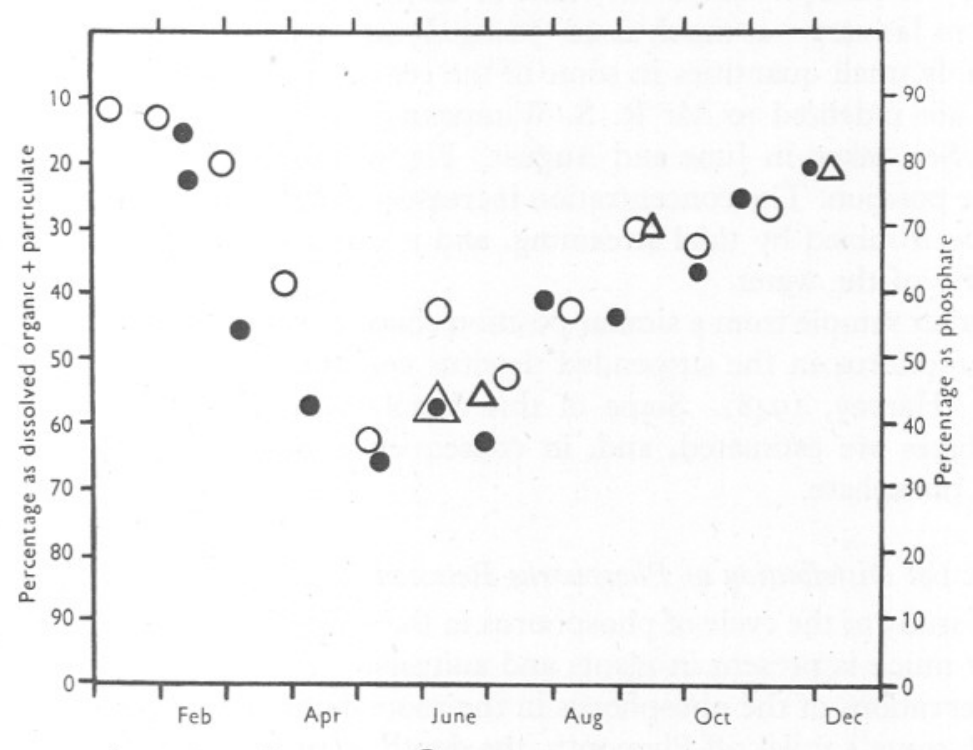
A 1947
1948
O 1949

Fig. 8. Diagram showing the seasonal variation in the percentage composition of the phosphorus in the water column 20 miles off-shore. 
There are difficulties in investigating the breakdown of organic phosphorus under natural conditions. If a sample of water is brought into the laboratory, conditions for such changes are entirely altered. The number of bacteria rise from a few hundred per c.c., or less in water well off-shore, to several million per c.c., the number of species falling. The surface of the container becomes coated with bacteria.

\section{Distribution of Phosphorus elsewhere in the English Channel}

In January 1947 areas of the sea were traversed during a cruise to the south and west where the water contained from $\mathrm{I} 2$ to $\mathrm{I} 8 \mathrm{mg}$. phosphate- $\mathrm{P} / \mathrm{m}{ }^{3}$ The areas with the highest content lay some 60 miles and some I20 miles to the westward of Plymouth (Cooper, private communication). Since then we have sampled water columns in the western part of the Channel with an average content of as little as Io $\mathrm{mg}$. 'total' $\mathrm{P} / \mathrm{m} .^{3}$ and as much as $23 \mathrm{mg}$.

Hence fluctuations in the total phosphorus content of the water column off Plymouth may be expected, as different water masses drift through the area.

All the estimates so far considered have been in waters which are clear and transparent, free from organic detritus, and in which a Secchi disk is visible to a considerable depth.

\section{Distribution of Phosphorus in Turbid Waters}

The turbid waters of the southern North Sea present a different picture from those in the western English Channel. They contain a very material quantity of phosphorus in the form of detritus, as has been shown by Kalle (1937) in January-as much as $40-50 \mathrm{mg} . \mathrm{P} / \mathrm{m} .^{3}$ at some inshore positions, and negligibly small quantities in some of the central and of the least turbid areas.

We are indebted to $\mathrm{Mr} \mathrm{R}$. S. Wimpenny for samples from the southern North Sea, taken in June and August. Fig. 9 shows the large quantity at an inshore position. The concentration increases with depth, in spite of the water being well mixed by tidal streaming, and it increases hand in hand with the turbidity of the water.

Another sample from a similar position showed that a material proportion of the phosphorus in the suspended detritus consisted of solid inorganic phosphates (Harvey, 1948). Some of this dissolves in the dilute acid in which phosphates are estimated, and, in consequence, appears in analyses as dissolved phosphate.

\section{On the Distribution of Phosphorus Between Water, Animals and Plants}

Any study of the cycle of phosphorus in the sea necessitates some knowledge of how much is present in plants and animals.

Observations of the phosphorus in the zooplankton below a square metre of the sea, some 5 miles off Plymouth, the depth being 50-55 m., had been made 
throughout I934, and that of the larger net-caught phytoplankton throughout several years. The quantities present below a square metre were very similar to those 20 miles off shore, in a depth of $70 \mathrm{~m}$., where most of the chemical data have been obtained. There were no observations concerning the smaller phytoplankton which escapes capture in a net having meshes of $42 \times 5 \mathrm{I} \mu$ and a great capacity for entangling smaller diatoms, nor concerning the average population density of fishes or of bottom-living organisms.

This necessitated an inquiry, the results of which are presented separately (Harvey, 1950, pp. 97-I37). Estimates, based on direct observation, of the quantity of phyto- and zooplankton below a square metre are incorporated in Table I (p. I5I).

Fish are both migratory and unevenly distributed; available data allow no more than a conjecture of the average quantity in the western part of the English Channel.

The bottom-living animals are also very unevenly distributed, and the number of quantitative observations in the area are relatively few and over a limited area. These allow no more than a probable conjecture of the average population density-some roo g. wet weight of living tissue below a square metre, the bulk of this being in animals having a life span of several years and living by filter-feeding on plankton organisms and organic detritus.

These estimates are incorporated in Fig. Io, which indicates the distribution of phosphorus in a water column, $70 \mathrm{~m}$. deep, as investigated during 1947-49. This is roughly the average depth of the western part of the English Channel.

No seasonal change in the quantity of pelagic and demersal fish is shown, on the assumption that month by month the rate of replacement of the biomass by growth balances losses by mortality. The quantity of bottom-living organisms, the infauna and epifauna, is also delineated as constant throughout the seasons, on the same assumption.

However, a large proportion of these bottom-living animals discharge planktonic larvae during the spring and early summer, larvae which contribute to the zooplankton, although not forming a large part of it, having only a short planktonic period and being for the most part soon eaten by other planktonic organisms. This discharge of larvae into the water is accompanied by a material loss of the parents' body substance, and suggests that the water is likely to contain a little more dissolved phosphorus during the spring and early summer, perhaps as much as $\mathrm{I} \mathrm{mg}$. $\mathrm{P} / \mathrm{m} .^{3}$ This possibility is compatible with the values for total phosphorus shown in Fig. 5 .

While considering the distribution between water and organisms, the state and quantity of phosphorus in bottom deposits deserves mention.

Muds rich in organic matter are laid down in estuaries, as those in the Clyde, Tyne and Tees which are rich in phosphate and, presumably, organic phosphorus. Their phosphate content decreases with depth, indicating slow solution into the overlying water. Conditions affecting solution in such a mud 


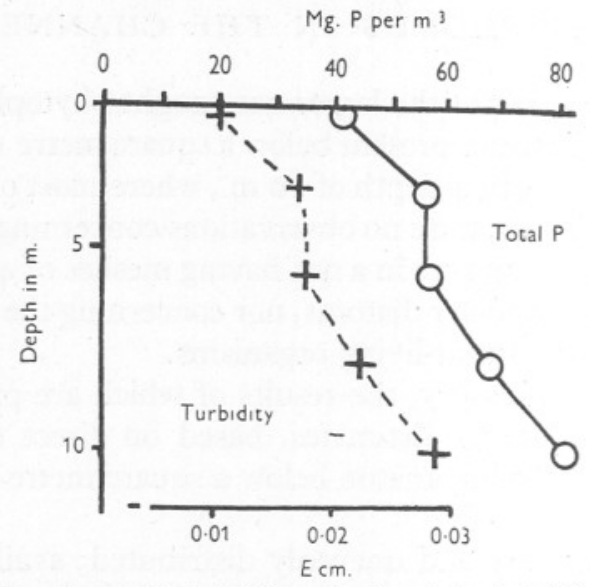

Fig. 9. Diagram showing change in total-P content and in turbidity with depth in turbid water. Samples collected off the Newcombe Bank, southern North Sea, June I947. Depth $12 \mathrm{~m}$.

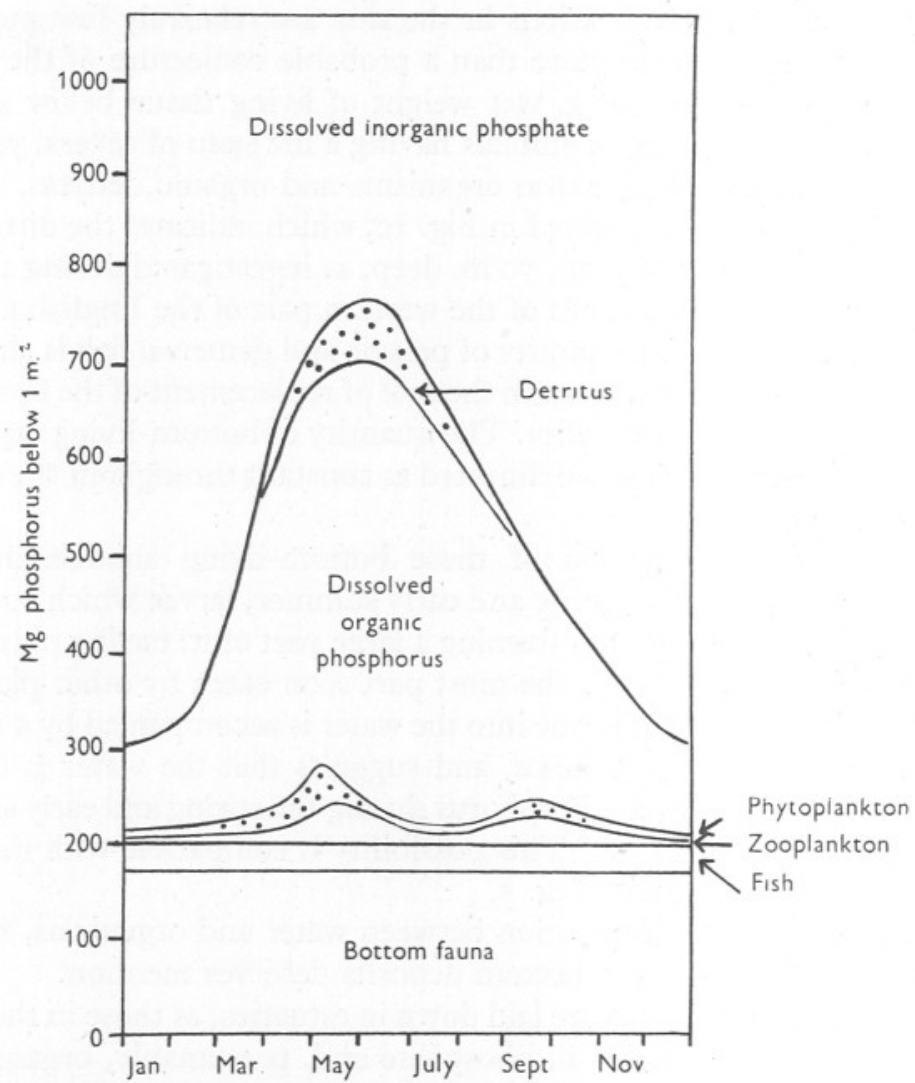

Fig. Io. Diagram showing distribution of phosphorus in water column $70 \mathrm{~m}$. deep, Plymouth area. (Phosphorus in solution and in detritus based on observations made in 1948 and 1949, in zooplankton based on observations made in 1935 farther in-shore, in fish and bottom fauna on computations, Harvey, I950, pp. 97-137.) 
have been studied by Stephenson (I949). These mud deposits occupy very restricted areas and are quite different from the floor of the open sea.

Yet, well off shore, the deposits are not devoid of phosphate. A fine silt or grey mud collected several miles off shore was found to contain $0.03 \% \mathrm{P}$-less than in soils, but a considerable quantity if any of it dissolves during the course of years.

The possibility of some small interchange between inorganic deposits and water cannot be dismissed.

\section{Phosphorus Content and Fertility of Water Masses}

The foregoing observations indicate that different water masses can be distinguished, one from another, by their total phosphorus content. Where, however, a water mass of less than 50 or $70 \mathrm{~m}$. depth overlies a different water mass, the distinction may be difficult, since the zooplankton cause a redistribution in the upper layers during summer.

The observations also show that geographical distribution in terms of total phosphorus content does not coincide with the distribution in terms of salinity. There is also evidence that the total phosphorus content bears a relation to the productivity and general fertility of the water.

Evidences of the dependence of the animal population upon the supply or production of plant life, and of the latter upon the supply of nutrient salts, is reviewed on pages 132 to 135 .

That the supply of phosphate varies with the total phosphorus in the water is implicit from the foregoing observations.

Hence it is expected that the mean concentration of total phosphorus in the water column denotes the potential fertility of the water occupying any particular area of the sea, its changing concentration providing a measure of changes from month to month and year to year in the supply of nutrient to the phytoplankton. It also appears to bear a broad relation to the population density of zooplankton which the water does maintain. An exact linear relation cannot be expected.

Observations of total phosphorus in the sea are limited, and comparable quantitative assessments of the population almost equally so. However, the observations summarized in the two following paragraphs point to this broad relation between total phosphorus in the water and the animal population maintained in it.

For a long period hauls have been made weekly off Plymouth with a ring trawl of I mm. mesh, each oblique haul filtering some $4000 \mathrm{~m} \cdot{ }^{3}$ of water. It was observed that the catches of macroplankton, including young fish, were particularly heavy during I924, I926 and I929, and that the winter maximum of phosphate at the beginning of each of these years was particularly high (Russell, 1935). This suggested that the water, rich in nutrient salts, was not displaced by noticeably poorer water during the first 8 or 9 months of each of 
these years: it also suggested that a rich phytoplankton resulted in a rich zooplankton and good survival of young fish. In Harvey, I950, fig. Io (p. I34 of this fournal) is plotted the average number of young fish, exclusive of clupeoids, caught per haul from June to October, against the phosphate maximum at the beginning of each year. A marked relation is seen, in spite of water movements having assuredly taken place between winter and summer on many occasions.

During the summer months in the Gulf of Maine, where the water contains over three times more phosphorus than the water off Plymouth has contained since 1947 , the average phytoplankton population during the summer months is considerably greater than in the water off Plymouth. The zooplankton below a square metre averaged during the summer months between 9 and $20 \mathrm{~g}$. dry weight, compared with I-2 g. in the waters off Plymouth (Riley \& Bumpus, I946).

Several other observations, which point towards this broad relation, are presented or are implicit in the considerations dealt with on p. I35.

We acknowledge with gratitude the assistance of Dr L. H. N. Cooper, Mr G. A. Steven and Mr P. G. Corbin, who collected for us many samples for analysis when on cruises in the Channel.

\section{SUMMARY}

Determinations of total phosphorus in water samples have shown areas in the western English Channel with water containing as little as Io $\mathrm{mg} . \mathrm{P} / \mathrm{m} .^{3}$, and other areas with double, and more than double, this concentration.

The integral mean concentration of total $\mathrm{P}$ in the water column, 20 miles off-shore from Plymouth, has fluctuated between Io and $\mathrm{I} 6 \mathrm{mg}$. P/m. ${ }^{3}$ since June 1947 .

The changes which have taken place in this integral mean concentration are attributed to different water masses, of different total phosphorus concentration, passing through the area, rather than to a seasonal change in the total phosphorus content of a water mass. No marked deposition of phosphoruscontaining detritus could be found.

Changes in this integral mean were not coincident with changes in salinity. The geographical distribution of total phosphorus does not coincide with the geographical distribution of salinity.

In winter, $85-90 \%$ of the total phosphorus is in the form of dissolved inorganic phosphate, which fell to $45 \%$ of the total in the early summers of I947-49.

The ratio of (dissolved inorganic) phosphate to organic phosphorus (in solution and in particles) has followed a regular seasonal change.

There is some diminution of total phosphorus in the upper $20 \mathrm{~m}$. layer in 
summer. This is attributed to zooplankton feeding in this layer by night and excreting some of their intake when they retire by day into deeper water.

Estimates have been made of the proportion of phosphorus in solution, in detritus, in plankton and in other animals.

At positions closer in-shore the water sometimes contained a little more and sometimes a little less total phosphorus.

Water collected from the surface of the sea was frequently richer in phosphate, and in total phosphorus, than water from below the surface.

Evidence is presented that the total phosphorus in the water distinguishes one water mass from another, is a measure of its potential fertility, bears a relation to the annual production of vegetation and of zooplankton, and also bears a relation to the survival of post-larval fish spawned in summer.

\section{REFERENCES}

ARMSTRong, F. A. J., I949. A source of error in the absorptiometric determination of inorganic and total phosphorus in sea water. Fourn. Mar. Biol. Assoc., Vol. xxviII, pp. $70 \mathrm{I}-5$.

COOPER, L. H. N., I948 $a$. The distribution of iron in the waters of the western English Channel. Fourn. Mar. Biol. Assoc., Vol. xxvir, pp. 279-313.

- I 9486 . Some chemical considerations on the distribution of iron in the sea. Fourn. Mar. Biol. Assoc., Vol. xxvII, pp. 314-2I.

Dietz, R., Emery, K. \& Shepard, F., I942. Phosphorite deposits on the sea floor off Southern California. Geol. Soc. Amer. Bull., Vol. 53, pp. 815-48.

Gorgy, S., Rakestraw, N. \& Fox, D., I948. Arsenic in the sea. Fourn. Mar. Res., Vol. 7, pp. 22-32.

Harvey, H. W., I948. The estimation of phosphate and of total phosphorus in sea waters. Fourn. Mar. Biol. Assoc., Vol. xxvir, pp. 337-59.

KALLE, K., I 933. Meereskundliche chemische Untersuchungen mit Hilfe des Zeißschen Pulfrich-Photometers. II. Ann. Hydrogr., Berlin, Bd. LXI, pp. I24-8.

- 1935. Meereskundliche chemische Untersuchungen mit Hilfe des Zeißschen Pulfrich-Photometers. V. Ann. Hydrogr., Berlin, Bd. LxIII, pp. 195-204.

— 1937. Nährstoff-Untersuchungen als hydrographisches Hilfsmittel zur Unterscheidung von Wasserkörpern. Ann. Hydrogr., Berlin, Bd. LXv, pp. I-I8.

KREPS, E., I934. Organic catalysts or enzymes in sea water. Fames fohnstone Memorial Volume, pp. 193-202. Liverpool.

Kreps, E. \& OsadchiK, M., I933. The organic phosphorus in the sea. Int Rev, Hydrobiol. Hydrog., Bd. 29, pp. 22 I-8.

NÜMANN, W., I94I. Der Nahrstoffhaushalt in der nordostlichen Adria. Thalassia, Bd. 5, H. 2, pp. I-68.

ORTON, J. H., I923. Summary of an account of investigations into the cause or causes of the unusual mortality among oysters in English oyster beds during 1920 and I921. Fourn. Mar. Biol. Assoc., Vol. xiII, pp. I-23.

Rakestraw, N. \& LutZ, F., I933. Arsenic in sea water. Biol. Bull. Woods Hole, Vol. LXV, pp. 397-40I.

Redfield, A. C., Smith, H. P. \& Ketchum, B., I937. The cycle of organic phosphorus in the Gulf of Maine. Biol. Bull. Woods Hole, Vol. LxxIII, pp. 42I-43. 
RILEY, G. \& Bumpus, D., I946. Phytoplankton-zooplankton relationships on Georges Bank. Fourn. Marine Res., Vol. 6, pp. 33-47.

RUSSELL, F. S., I935. The seasonal abundance and distribution of the pelagic young of teleostean fishes caught in the ring-trawl in offshore waters in the Plymouth area. Part II. Fourn. Mar. Biol. Assoc., Vol. xx, pp. I47-79.

Serwell, H. R. \& Serwell, G. E., I934. Über den Gesamtphosphorgehalt des Seewassers im westlichen Nordatlantischen Ozean. Ann. Hydrograph., Berlin, Bd. LXII, pp. 7-I3.

SöderströM, A., I924. Das Problem der Polygordius-Endolarve. Uppsala \& Stockholm, I68 pp.

STEPHENSON, W., 1949. Certain effects of agitation upon the release of phosphate from mud. Fourn. Mar. Biol. Assoc., Vol. xxviII, pp. 371-80.

Wilson, D. P., I932. On the mitraria larva of Owenia fusiformis Delle Chiaje. Phil. Trans. Roy. Soc. B, Vol. 22, pp. 23I-334. 


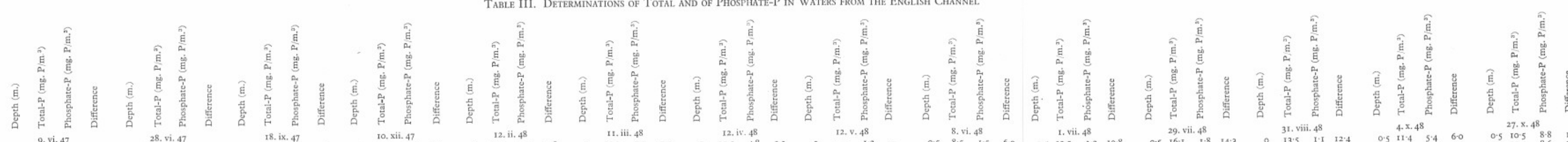

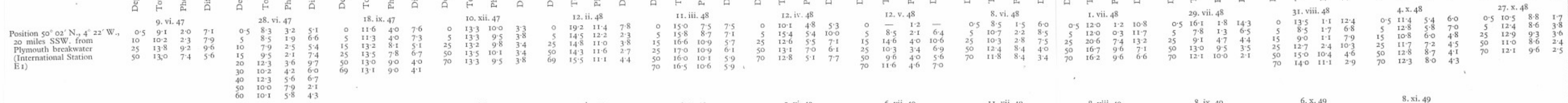

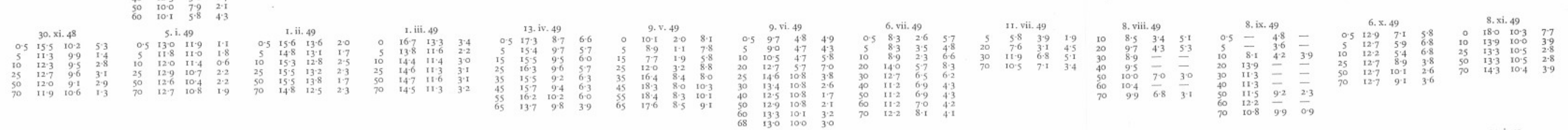

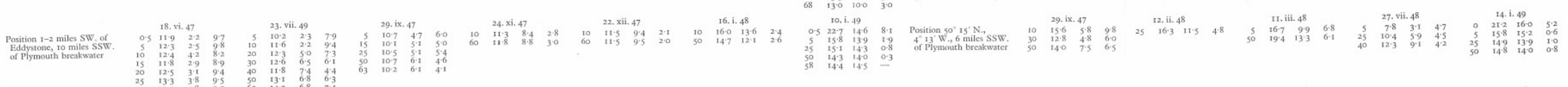

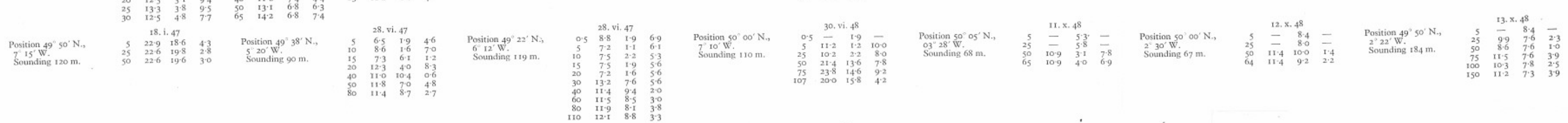

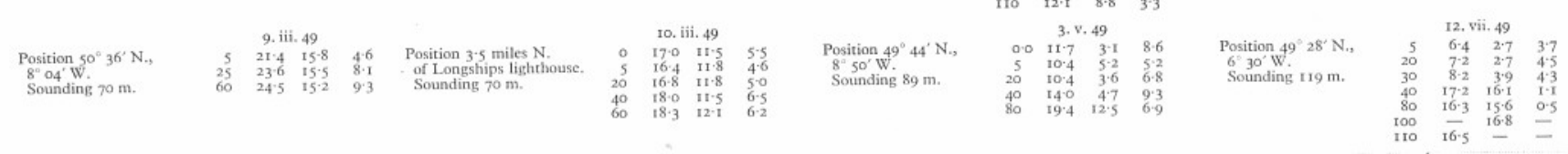

